\title{
THE RELATIONSHIP BETWEEN PERSONALITY TRAITS AND VOCATIONAL INTERESTS
}

\author{
GIDEON P DE BRUIN \\ Department of Psychology \\ University of Stellenbosch
}

\begin{abstract}
This study examined the relationship between vocational interests and basic personality traits. The interest fields of the 19-Field-Interest Inventory were related to the second order factors of the 16 Personality Factor Questionnaire by means of a factor extension analysis. The results showed that extroverts tend to be interested in fields related to social contact and the influencing of other people. Emotionally sensitive individuals tend to be interested in the arts and languages. Independent individuals tend to be interested in creative thinking. The implications of the findings for career counselling are discussed.
\end{abstract}

\section{OPSOMMING}

Hierdie studie het ondersoek ingestel na die verband tussen beroepsbelangstellings en basiese persoonlikheidstrekke. Die 19 belangstellingsvelde van die 19-Veld-belangstellingsvraelys is aan die hand van 'n faktorverlengingsontleding met die tweede orde faktore van die 16-Persoonlikheidsfaktorvraelys in verband gebring. Die resultate dui daarop dat ekstroverte geneig is om in velde wat sosiale kontak en die beïnvloeding van mense behels, belang te stel. Emosioneel sensitiewe individue is geneig om in kunssinnge en taal verwante velde belang te stel. Onafhanklike individue is geneig om in kreatiewe denke belang te stel. Die implikasies van die resultate vir loopbaanvoorligting word bespreek.

The aim of this study was to investigate the relationship between vocational interests, as measured by the 19-Field-Interest Inventory (19FII), and personality traits, as measured by the 16 Personality Factor Questionnaire (16PF). Ackerman (1997) proposed two reasons why the study of the relationships between interests and personality traits are important. In the first place it is a common scientific goal to investigate the relationships between different constructs. This strategy may lead to important new scientific discoveries. The second reason is that the study of the relationships between interests and personality traits will reveal what they have in common and what unique information they can provide. This information is potentially useful in the career counselling context.

Recently, several studies have investigated the overlap between vocational interests and personality traits (Blake \& Sackett, 1999; Carless, 1999; De Fruyt \& Mervielde, 1997; Gottfredson, Jones \& Holland, 1993; Hogan \& Blake, 1999; Katz, Joyner \& Seaman, 1999; Tokar \& Swanson, 1995). The results of these studies reveal a consistent but relatively weak pattern of relationships between interests and personality traits. Most of the recent studies made use of Holland's (1997) hexagonal model of vocational interest types and the five-factor model of personality traits (Wiggins \& Trapnell, 1997). Holland proposes six broad and fundamental interest or vocational personality types: (a) Realistic, (b) Investigative, (c) Artistic, (d) Social, (e) Enterprising, and (f) Conventional. The five-factor model of personality traits proposes five broad and fundamental personality traits: (a) Extroversion, (b) Neuroticism, (c) Agreeableness, (d) Conscientiousness and (e) Openness to Experience (see Digman, 1990; John, 1990; and Wiggins \& Trapnell, 1997 for full discussions of these factors). The results of studies investigating the correspondence between Holland's interest types and the five-factor model generally show the following: Extroversion is related to Enterprising and Social interests, Openness to Experience is related to Investigative and Artistic interests, and Conscientiousness is related to Conventional interests (Blake \& Sackett, 1999; de Fruyt \& Mervielde, 1997; Gottfredson et al, 1993; Hogan \& Blake, 1999; Holland, 1999; Tokar \& Swanson, 1995).

These findings are consistent with Holland's (1997) theory and provide support for the construct validity of Holland's model of vocational interests and the five-factor model of personality. From a scientific perspective, the overlap between the two models provides a parsimonious view of how interests and

Requests for copies should be addressed to: GP de Bruin, Department of Psychology, University of Stellenbosch, Private Bag X1, Matieland, 7602 personality traits are related. However, from a practical perspective, predictive and explanatory power is lost with broad constructs such as Holland's interest types and the broad traits of the five-factor model (Mershon \& Gorsuch, 1989; Ashton, Jackson, Paunonen, Helmes \& Rothstein, 1995). In the career counselling context it often is desirable to have knowledge about an individual's specific interests. From this perspective it may be useful to know how such specific and narrow fields of interest relate to personality traits.

The 19FII and the 16PF are two commonly used instruments for career counselling purposes in South Africa. Each instrument is thought to provide useful information in the career counselling process. Career counsellors usually hope to find a logically consistent pattern of vocational interests and personality traits and it is hoped that an individual's vocational interests will be compatible with his or her personality traits. For instance, on theoretical grounds career counsellors would probably expect extroverted individuals to be interested in occupations that involve opportunities for social contact.

The 19FII provides measures for 19 specific fields of interest that are narrower than the six types of Holland's model. However, conceptual and factor analyses have shown that the correlations between the 19 fields of the 19FII can be explained by six broad factors that appear to correspond with Holland's interest types (De Bruin \& du Toit, 1995; Langley, 1989; Malan, 1987). The relationships between the 19FII fields and Holland's types are summarised in Table 1 . The table is intended to serve as a heuristic summary of the relationship between the 19FII fields and Holland's interest types. It should be emphasized, however, that the empirical relationship between the 19FII scales and Holland's types are more complex than what is presented in Table 1. For instance, several of the 19FII fields are related to more than one Holland type. However, in the table each 19FII field is linked only with the Holland type that it probably is most strongly associated with. There are further aspects of Table 1 that need to be clarified. Firstly, it may appear theoretically inconsistent that the Practical-Male field is associated with the Realistic type, while the Practical-Female field is associated with the Artistic type. Inspection of the items of the Practical-Male field reveals that they reflect stereotypically male activities, such as repairing broken appliances and working with hand tools. These activities are clearly consistent with the activities associated with the Realistic type. The items of the Practical-Female scale reflect stereotypical female activities, such as preparing meals and making clothes or soft furniture, cooking, and needlework. These activities involve an aesthetic element and in this respect the Practical-Female scale is associated with the Artistic type. 
TABLE 1

THE RELATIONSHIPS BETWEEN THE 19FII AND HOLLAND'S INTEREST TYPES

\begin{tabular}{ll}
\hline Holland fields & 19FII fields \\
\hline Realistic & Practical-Male \\
& Nature \\
& Sport \\
Investigative & Science \\
& Creative Thinking \\
& Numerical \\
Artistic & Fine Arts \\
& Performing Arts \\
& Language \\
& Practical-Female \\
Social & Sociability \\
& Welfare \\
Enterprising & Travel \\
& Law \\
Conventional & Public Speaking \\
& Business \\
\end{tabular}

Roos (1988) investigated the relationships between the fields of the 19FII and the 14 personality traits of the High School Personality Questionnaire (HSPQ). Roos (1988) performed a principal factor analysis on the intercorrelations of the interest and personality scales. He extracted and rotated seven factors. The first two factors were characterised by high loadings of the HSPQ scales and the remaining five factors were characterised by high loadings of the 19FII scales. The most significant findings of the study were (a) that the extroversion factor is related to two interest scales, namely Sociability and Sport, and (b) that emotional sensitivity is related to artistically related interest fields, namely Performing Arts, Fine Arts, Language and Practical-Female.

The analytic strategy followed in the present study was to subject the 16PF scales to a factor analysis. The resulting second order factors were then extended to the scales of the 19FII by means of Gorsuch's (1997) factor extension analysis procedure. With this procedure a subset of a larger set of variables is subjected to a factor analysis. These variables are referred to as core variables. In the present study the $16 \mathrm{PF}$ scales served as the core variables. The resulting factors are then extended to the variables that were not included in the factor analysis. These variables are referred to as extension variables. In the present study the 19FII fields served as the extension variables. Gorsuch (1997) explains that the overlap between the extension variables and the factors can only be influenced by the overlap between the core variables and the extension variables. The use of the factor extension analysis will allow for an examination of how vocational interests fit into the space defined by the factors of the $16 \mathrm{PF}$.

\section{METHOD}

\section{Participants}

The participants were 1502 first year university students at a South African university. The mean age of the students was 18 years and there were approximately equal numbers of males and females. The students represented all the faculties at the university.

\section{Measuring instruments}

16 Personality Factor Questionnaire (16PF)

The 16PF (Form A) was used to obtain measures of the participants' personality traits. The 16PF flowed from Cattell's extensive factor analytic research program into the structure of human personality. He identified about 20 basic normal personality traits, of which 16 are measured by the 16PF. One of the $16 \mathrm{PF}$ scales, namely Scale $\mathrm{B}$, measures intelligence rather than personality and this scale was not included in the present analysis. Previous factor analytic studies have shown that the correlations among the 15 remaining scales can be summarised and explained in terms of five second-order factors, namely Extroversion, Anxiety, Tough Poise, Independence and Control (Hofer et al., 1997; Krug \& Johns, 1986). The second-order factors are broader than the first-order factors and explain a wider range of behaviour. The second-order factors are also more reliable and replicable (in a factor analytic sense) than the first-order factors (Hofer et al., 1997; Krug \& Johns, 1986).

19-Field-Interest Inventory (19FII)

The 19FII was constructed by Fouché and Alberts (1971) and provides normative scores for 19 fields of interest. The 19FII is intended for use with Grade 10 to Grade 12 pupils, but the instrument is also used in higher education institutions. The manual reports split-half reliability coefficients ranging between .88 and .98 for high school boys and girls. Overall, the reliability of the 19FII for this group can be described as satisfactory. The participants in the present study are similar in age and educational level to the Grade 12 normative group and it is assumed that the present 19FII scores are also reliable. Nicol (1978) demonstrated that the 19FII effectively discriminates between university students in different study fields.

\section{RESULTS AND DISCUSSION}

On the basis of previous factor analytic studies, it was expected that the correlations between the $1516 \mathrm{PF}$ scales would be adequately and meaningfully explained by five second order factors (Hofer et al., 1997; Krug \& Johns, 1986). Accordingly, five second order factors were extracted by means of the principal axis method with iterated communalities. The factors were rotated to simple structure according to the promax criterion $(k=4)$. The resulting factor pattern matrix and the correlations between the factors are reported in Tables 2 and 3 .

TABLE 2

PROMAX ROTATED FACTOR PATTERN MATRIX OF THE 16PF SCALES

\begin{tabular}{lrrrrr}
\hline 16PF Scale & \multicolumn{5}{c}{ 16PF second-order factors } \\
& I & II & III & IV & V \\
\hline A (Warmth) &. .59 & .33 & .18 & -.12 & .15 \\
C (Emotional Stability) & .25 & -.01 & .38 & .18 & -.37 \\
E (Dominance) & $\underline{.54}$ & -.07 & -.17 & .66 & .01 \\
F (Liveliness) & $\underline{.76}$ & -.03 & -.03 & .31 & .05 \\
G (Rule-consciousness) & .06 & -.11 & .73 & -.16 & .11 \\
H (Social Boldness) & $\underline{.81}$ & .08 & .03 & .29 & -.18 \\
I (Sensitivity) & .05 & .69 & -.10 & -.10 & .00 \\
L (Vigilance) & .06 & -.12 & -.02 & .37 & .44 \\
M (Abstractedness) & -.03 & .54 & -.03 & .17 & .13 \\
N (Privateness) & -.08 & -.11 & .40 & .20 & .15 \\
O (Apprehension) & -.05 & .09 & .11 & -.10 & .72 \\
Q1 (Openness to Change) & .04 & .11 & .05 & .41 & -.07 \\
Q2 (Self-reliance) & $\underline{.62}$ & .18 & .02 & .18 & -.04 \\
Q3 (Perfectionism) & -.15 & .05 & .57 & -.09 & -.19 \\
Q4 (Tension) & -.04 & .04 & -.10 & .07 & .73 \\
\hline
\end{tabular}

Note. All factor pattern coefficients are rounded to two decimal places. All absolute factor pattern coefficients of .30 and higher are underlined. I = Extroversion; II = Tough Poise; III = Control; IV = Independence; V = Anxiety.

Inspection of Table 2 reveals that the five factors correspond closely with the well-known 16PF second-order factors reported by Hofer et al. (1997) and Krug and Johns (1986). Following Krug and Johns (1986) these factors are labeled as Extroversion, Tough Poise, Control, Independence and Anxiety.

TABLE 3

INTERCORRELATIONS OF THE 16PF SECOND-ORDER FACTORS

\begin{tabular}{lrrrrr}
\hline & E & TP & C & I & A \\
\hline Extroversion (E) & 1.00 & & & & \\
Tough Poise (TP) & -.03 & 1.00 & & & \\
Control (C) & -.02 & .19 & 1.00 & & \\
Independence (I) & -.11 & .14 & .32 & 1.00 & \\
Anxiety (A) & .00 & .27 & -.37 & .03 & 1.00 \\
\hline
\end{tabular}

Note. All correlations are rounded to two decimal places. 
The second-order factors of the $16 \mathrm{PF}$ were extended to the 19 scales of the 19FII by means of Gorsuch's (1997) factor extension analysis procedure (see Table 4). In the following paragraphs the relationships between the personality factors and the interest scales are discussed.

TABLE 4

CORRELATIONS BETWEEN 19FII FIELDS AND 16PF SECOND-ORDER FACTORS

\begin{tabular}{lrrrrr}
\hline Interest field & \multicolumn{5}{c}{ 16PF second-order factors } \\
& I & II & III & IV & V \\
\hline Fine Arts & .02 & .15 & -.02 & .14 & .04 \\
Clerical & -.06 & .06 & .06 & -.10 & .10 \\
Welfare & .15 & .33 & .06 & -.11 & .06 \\
Performing Arts & .13 & .26 & -.01 & .07 & .07 \\
Science & -.15 & -.13 & .10 & .17 & -.13 \\
Historical & -.07 & .14 & .00 & .12 & .08 \\
Public Speaking & .38 & .14 & .03 & .18 & .05 \\
Numerical & -.12 & $\underline{-.25}$ & .11 & .11 & -.07 \\
Sociability & .57 & .07 & .01 & .03 & .07 \\
Creative Thinking & .04 & -.05 & .14 & .24 & -.05 \\
Travel & .25 & .08 & -.02 & .07 & .11 \\
Practical-Female & .03 & .16 & -.01 & -.02 & .05 \\
Law & .22 & .06 & .01 & .16 & .10 \\
Sport & .23 & -.15 & .01 & .06 & -.07 \\
Language & .07 & .33 & -.07 & .09 & .14 \\
Service & .20 & .14 & -.03 & -.06 & .12 \\
Practical-Male & -.13 & $\underline{-.22}$ & .07 & .14 & -.13 \\
Business & .09 & $\underline{-.20}$ & .02 & .15 & .02 \\
\hline
\end{tabular}

Note. All correlations are rounded to two decimal places. All absolute correlations of 20 and higher are underlined. I = Extroversion; II = Tough Poise; III = Control; IV = Independence; $\mathrm{V}=$ Anxiety.

\section{Factor 1 (Extroversion)}

The following 19FII fields were meaningfully correlated $(r \geq .20)^{1}$ with the Extroversion factor: Sociability, .57; Public Speaking, .38; Travel, .25; Sport, .23; Law, .22; and Service .20. These fields relate to contact with other people on mainly two levels: (a) recreation (Sociability, Travel and Sport), and (b) influencing of other people (Law and Public Speaking). The high correlations of Sociability and Public Speaking with the Extroversion factor clearly demonstrate extroverts' need for contact with other people.

\section{Factor 2 (Tough Poise)}

Low scores for the Tough Poise factor indicate tough-mindedness and high scores indicate emotional sensitivity. This factor is similar in meaning to the Openness to Experience factor of the five-factor model (Cattell, 1995). The following 19FII fields were meaningfully correlated with the Tough Poise factor: Welfare, .33; Language, .33; Performing Arts, .26; Numerical, -.25; Practical-Male, -.22; and Business, -.20. It is interesting that three of the 19FII fields correlated positively (Welfare, Language and Performing Arts) and three correlated negatively (Numerical, Practical-Male and Business) with the Tough Poise factor. The three fields that correlated positively all relate to contact with people and communication, whereas the three fields that correlated negatively are related to "things" and abstract concepts (numbers). The positive association of Language and Performing Arts with Tough Poise provide support for the link between Holland's (1997) Artistic field and the Openness to Experience factor of the five-factor model. The remaining correlations indicated that emotionally sensitive individuals are interested in the welfare of others and are not interested in fields that mostly relate to "things" (i.e. Business, Numerical and Practical-Male) rather than people.

\section{Factor 3 (Control)}

High scores for the Control factor are associated with perfectionism and adherence to societal norms and rules. Low scores are associated with a lack of personal control and a disregard

\footnotetext{
${ }^{1}$ Because of the large sample size and the resulting high statistical power of even very small correlations between the interest fields and personality traits are statistically significant. Therefore, Cohen's (1988) guidelines for the interpretation of correlation coefficients in psychological research were followed. According to Cohen correlations of .20 can be described as moderate in strength.
}

for societal norms and rules. This factor is similar to the Conscientiousness factor of the five-factor model (Noller, Law \& Comrey, 1987). No 19FII field had a meaningful correlation with the Control factor. However, previous studies have suggested a link between Conscientiousness (or Control) and the Conventional interest type (Blake \& Sackett, 1999; Hogan \& Blake, 1999). The lack of a similar finding in the present study suggests that the 19FII possibly does not provide adequate measurement of Holland's Conventional type.

\section{Factor 4 (Independence)}

High scores for the Independence factor are associated with a critical and domineering interpersonal style. Low scores are associated with group dependence and submissiveness. This factor is similar to the Agreeableness factor of the five-factor model. Only one 19FII field had a positive and meaningful correlation with the Independence factor, namely Creative Thinking $(r=.24)$, suggesting that independent individuals like to generate alternative and new ideas.

\section{Factor 5 (Anxiety)}

High scores for the Anxiety factor indicate emotional instability and a lack of self-confidence. Low scores indicate emotional control and high self-confidence. This factor is similar to the Neuroticism factor of the five-factor model. No 19FII field had a meaningful correlation with Anxiety. Previous studies also failed to demonstrate a link between Anxiety and vocational interests (de Fruyt \& Mervielde, 1997; Gottfredson et al, 1993; Tokar \& Swanson, 1995).

In summary, the findings show that three second-order personality factors, namely Extroversion, Tough Poise and Independence have meaningful relationships with vocational interests. Individuals with high scores for Extroversion are interested in fields that relate to contact with other people. Individuals with low scores for Tough Poise are interested in the performing arts and languages, but tend to move away from business, numbers and stereotypical practical-male activities. Individuals with high scores for the Independence factor are drawn towards creative thinking.

It should be noted, however, that the correlations between the personality factors and interest scales are relatively weak. Thus, although there are psychologically meaningful relationships between the two sets of variables, personality traits and vocational interests appear to represent two clearly different domains of behaviour. These findings are not consistent with Holland's (1999) strong assertion that interest inventories are also personality inventories. Hogan and Blake (1999, p. 54) explain that interests reflect a person's "goals, values and aspirations", while personality traits reflect a person's typical behaviour. In this sense interest questionnaires and inventories directly tap into an individual's identity, while personality questionnaires and inventories directly tap into an individual's characteristic behaviour and only indirectly into his or her identity. Hogan and Blake (1999, p. 54) further contend that while "...interest measures tell us how much an individual will like an occupation, personality measures tell us about the social skills and drives necessary to succeed once in the occupation." Thus, although the personality traits of Anxiety and Control appear to be unrelated to vocational interests, they may be important in the career counselling context because they provide information about how the individual is likely to behave in the work place.

It is concluded that the personality trait measures, such as the $16 \mathrm{PF}$, and vocational interest measures, such as the 19FII, can each contribute potentially useful information to the career counselling process. By measuring personality traits and vocational interests the career counsellor is likely to obtain an integrated and comprehensive picture or understanding of his or her client. Similarly, the client is likely to gain a more comprehensive understanding of him or herself if personality traits and vocational interests form part of the psychological assessment process. 


\section{REFERENCES}

Ackerman, P.L. (1997). Personality, self-concept, interests, and intelligence: Which construct doesn't fit? Journal of Personality, 65, 171-204.

Ashton, M.C., Jackson, D.N. Paunonen, S.V., Helmes, E. \& Rothstein, M.G. (1995). The criterion validity of broad factor scales vs specific factor scales. Journal of Research in Personality, 29, 432-442.

Blake, R.J., \& Sackett, S.A. (1999). Holland's typology and the five factor model: A rational-empirical analysis. Journal of Career Assessment, 7, 249-279.

Carless, S.A. (1999). Career assessment: Holland's vocational interests, personality characteristics, and abilities. Journal of Career Assessment, 7, 125-144.

Cattell, H.E.P. (1995). Some comments on a factor analysis of the 16PF and the NEO Personality Inventory-Revised. Psychological Reports, 77, 1307-1311.

Cattell, R.B., Eber, H.W. \& Tatsuoka, M. (1970). Handbook for the 16PF. Champagne, Il: IPAT.

Cohen, J. (1988). Statistical power analysis for the behavioral sciences. (2nd ed.). Hillsdale, NJ: Erlbaum.

De Bruin, G.P. \& du Toit, K. (1995). Die faktorstruktuur van die 19-Veldbelangstellingsvraelys en Holland se struktuur van belangstellings. Journal of Industrial Psychology, 21(3), 24-28.

De Fruyt, F., \& Mervielde, I. (1997). The five factor model of personality and Holland's RIASEC interest types. Personality and Individual Differences, 23, 87-103.

Digman, J.M. (1990). Personality structure: Emergence of the five-factor model. Annual Review of Psychology, 41, 417-440.

Fouché, F.A., \& Alberts, N.F. (1971). Manual for the 19-Field-Interest Inventory (19-FII). Pretoria: Human Sciences Research Council.

Gorsuch, R.L. (1997). New procedure for extension analysis in exploratory factor analysis. Educational and Psychological Measurement, 57, 725-740.

Gottfredson, G.D., Jones, E.M., \& Holland, J.L. (1993). Personality and vocational interests: The relation of Holland's six interest dimensions to five robust dimensions of personality. Journal of Counseling Psychology, 40, 518-524.

Hofer, S.M., Horn, J.L., \& Eber, H.W. (1997). A robust fivefactor structure of the 16PF: Strong evidence from independent rotation and confirmatory factorial invariance procedures. Personality and Individual Differences, 23, 247-269.

Hogan, R., \& Blake, R. (1999). John Holland's vocational typology and personality theory. Journal of Vocational Behaviour, 55, 41-56.
Holland, J.L. (1997). Making vocational choices. Odessa, Fl: Psychological Assessment Resources.

Holland, J.L. (1999). Why interest inventories are also personality inventories. In M.L. Savickas \& A.R. Spokane (Eds.), Vocational interests: Meaning, measurement and counseling use (pp. 87-101). Palo Alto, CA: Davies-Black.

John, O.P. (1990).

The "Big Five" factor taxonomy: Dimensions of personality in the natural language and in questionnaires. In L.A. Pervin (Ed), Handbook of personality: Theory and research (pp. 66-100). New York, NY: Guilford.

Katz, L., Joyner, J.W. \& Seaman, N. (1999). Effects of joint interpretation of the Strong Interest Inventory and the Myers-Briggs Type Indicator in career choice. Journal of Career Assessment, 7, 281-298.

Krug, S.E. \& Johns, J.F. (1986). A large scale cross-validation of second-order personality structure defined by the $16 \mathrm{PF}$. Psychological Reports, 59, 683-693.

Langley, R. (1989). Gerekenariseerde loopbaanvoorligting: 'n Evaluering van die DISCOVER-stelsel. (Computerised career counseling: An evaluation of the DISCOVER system). Unpublished doctoral dissertation. Johannesburg, Rand Afrikaans University.

Mershon, B. \& Gorsuch, R.L. (1988). Number of factors in the personality sphere. Journal of Personality and Social Psychology, $55,675-680$.

Nicol, J. (1978). Die differensiële waarde van die 19-Veld-Belangstellingsvraelys. (The differential value of the 19-Field-Interest Inventory). Unpublished master's thesis. Pretoria, University of Pretoria.

Noller, P., Law, H., \& Comrey, A.L. (1987). Cattell, Comrey, and Eysenck personality factors compared: More evidence for the five robust factors? Journal of Personality and Social Psychology, 53, 775-782

Roos, W.L. (1988). Die verband tussen persoonlikheid en belangstelling: 'n eksploratiewe ondersoek. (The relationship between personality and interests: An exploratory investigation.) Pretoria: Human Sciences Research Council.

Tokar, D.M., \& Swanson, J.L. (1995). Evaluation of the correspondence between Holland's vocational personality typology and the five factor model of personality. Journal of Vocational Behavior, 46, 89-108.

Wiggins, J.S. \& Trapnell, P.D. (1997). Personality structure:The return of the big five. In R. Hogan, J. A. Johnson, \& S.R. Briggs (Eds.), Handbook of personality psychology (pp. 737758). San Diego, CA: Academic. 